\title{
The Analysis of Presuposition on the Conversation of Acehnese and Javanese Ethnic in Gampong Geudubang Jawa, Langsa City
}

\author{
Desy Irafadillah Effendi*, Ramdan Afrian, Ayu Suciani \\ Department of Indonesian Education, Faculty of Teacher Training and Education \\ Universitas Samudra \\ Langsa, Indonesia \\ *desyirafadillah@unsam.ac.id
}

\begin{abstract}
This study aims to describe the dominant presupposition found in the Acehnese and Javanese tribes in Geudubang Jawa Village, Langsa City. This study used a qualitative research approach producing written descriptive data. Data in this study are drawn from conversations of the Acehnese and Javanese tribes in Geudubang Jawa village. There are two ways used in the data collection techniques, they are observation and note-taking. The research reveals that the conversations of Acehnese and Javanese ethnics in Geudubang Jawa village are similar to the presuppositions used by the community in general which consist of 1) factive presuppositions; 2) existential presupposition; 3) structural presupposition; 4) non-factive presupposition; 5) lexical presupposition; and 6) counterfactual presuppositions. The dominant presupposition found in the conversations of these ethnicities is factive.
\end{abstract}

Keywords-presupposition, Acehnese, Javanese, Tribe, Langsa

\section{INTRODUCTION}

Language is a communication tool used by humans. The use of language as a means of communication should have a clear meaning, purpose, and implication so that the interlocutor can understand the meaning conveyed [1]. A speech event requires the same understanding of a context between speakers and interlocutors to avoid miscommunication. Oral and written communication must have topics that are discussed between one another in expressing thoughts, opinions, and cooperation.

The conversation is a verbal interaction that takes place in a systematically orderly manner involving two or more parties to achieve certain goals. Apart from the context that is being discussed, a conversation also plays an important role in human life because it links the society. The exchange of information or opinions in a conversation has an impact on the interpretation or realization of the conversation. If the conversation is understood properly according to the interlocutor's intention, the information can be absorbed well.

A conversation has implicit and explicit meanings. however, an explicit conversation does not always correspond with the speaker's intention. therefore, every utterance has an implied meaning that must be adapted to the contexts and the intentions of the speaker. The meaning of a conversation is not only focused on its written or verbal meaning, but also to the other implicit meanings of the conversation [2]. In fact, during a conversation, speakers sometimes do not realize that they have used a presupposition before speaking.

The presupposition of a speech uttered by a speaker has an implicit and explicit meaning or the speaker has conjecture before uttering the conversation. A presupposition is something that is assumed by the speaker to be an event before producing a speech [3].

Geudubang Java village is a village located in Langsa Baro sub-district, Langsa City, Aceh. This village has a dominant population of two ethnic groups; Acehnese and Javanese. in daily communication, the Javanese community often uses their local language. Although the two ethnicities use different language, it does not cause any conflict in the village.

\section{Methodology}

This research is a qualitative descriptive study. The data collected in this study are utterances extracted from the daily conversations of the Acehnese and Javanese ethnics in Geudubang Jawa Village in the form of oral data observed by the researchers. The data collection technique is done by using a listening and note-taking technique. The listening method is a method used in language by listening to the use of language as the study object [4]. The observation technique is carried out because the object under study is utterances obtained from public daily conversations then proceed with the note-taking technique, that is, to record data with stationeries or other instruments. Sudaryanto [4] said that note-taking techniques are carried out after the first or second technique has been used by certain writing instruments.

The research population was divided into two groups, the Javanese ethnic and the Acehnese ethnic. The research sample was randomly selected using the snowball sampling technique. The study lasts 3 months. The acehnese and javanese conversations studied are daily conversations. 
The instrument in this study is the data format, the researcher themself, and recorders. A research instrument is a tool used to collect data in research [1]. When listening, the instruments used are stationaries and handphones. Next is the data analysis technique. The data analysis techniques in this research are: 1) data reduction, that is, after the data is collected, the researcher reduces the data or combines the same data from different subjects; 2) the coding process (assigning serial numbers), the purpose of this technique is to make it easier for researchers to discuss the facts with the theories; 3) data analysis; 4) concluding.

\section{RESULTS}

This study found that there are six types of presuppositions in the speech of the Geudubang Jawa community. Those are active presupposition, existential presupposition, structural presupposition, non-factive presupposition, lexical presupposition, and counterfactual presupposition.

People in this village predominantly use Active Presupposition in their communication. In detail, the results of the data analysis show that there are 7 active presuppositions, 6 existential presuppositions, 5 structural presuppositions, 4 nonfactive presuppositions, 4 lexical presuppositions, and 3 counterfactual presuppositions.

\section{A. Factive Presupposition}

\section{B. Data (1)}

A: Wes masak sampeyan Ros?

'Have you cooked, Ros?'

B: Uwes, nembeke siap ni wak. meriang badan ku pun iki duka kenging punapa saking kala wingi.

'I'm done. I've just finished, Wak. I don't know why. my body has been feeling unwell since yesterday.

'Analysis: The dialogue has the presupposition that Ros hasn't cooked yet because she feels unwell, an assumption is seen when Beth asks Ros Wes masak sampeyan ros? 'Have you cooked, Ros?'. This speech indicates a factive presupposition. The dialogue between the two speakers clearly shows factual conditions and follows the truth verb [2]

Data (2)

A: Ya, aku cepet ngrampungake pangananku

'OK, I'll finish my meal quickly'

B: Ya, bakal nunggu sampeyan sawise kita langsung mangkat 'Yes, I am going to wait for you, after that, we will be leaving immediately.'

Analysis: This conversation has the presumption that person $\mathrm{A}$ is eating, and they will be leaving. This is indicated by the statement of person A who states that he/she will quickly finish his/ her food. This speech can be interpreted as the truth that he/ she is eating, then the B says that he/ she will wait. This statement proves the truth and reality. This sentence indicates a factive presupposition [3]
Data (3)

A: Kemana mamak?

'where is mom?'

B: Lungo ke kede.

'(she's) going to the shop'

Analysis: The conversation has the presupposition that mamak (mother) is away and there is a shop. the context is that when $\mathrm{A}$ realizes that mother is not there, so he/ she asks B, kemana mamak? 'where is mamak?'.

This speech indicates that the speech is a factive presupposition, which is seen that the presuppositions follow the verb and can be proven its existence and truth [5,6].

Data (4)

A: Mangan pak

'Eat, sir'

B: Terima kasih. Wis sadurunge

'Thank you. I have eaten'

'Analysis: This speech has the presupposition that the man has not eaten yet, also, as a common courtesy to offer someone food before eating by saying mangan, pak, 'Eat, sir', but B responds by confirming that he has already eaten. A received a polite refusal answer. This presupposition signifies a factive presupposition because it follows a verb and a fact statement [2].

Data (5)

A: Jih meukarat ih, hana sadar hp ih ka tinggai

'He was in a hurry; he didn't notice his cellphone was left behind'

Analysis: This speech has the presupposition that someone is in a hurry, which is stated in the speech ih meukarat ih, hana sadar hTidak ada di daftar referensi mohon tambahkan

$\mathrm{p}$ ih ka tinggai which means 'He is too hasty and does not realize that his cellphone is left behind'. The cellphone left behind becomes factual and its existence can be proven. This speech is a type of factive presupposition [2].

Data (6)

A: Gara-gara virus korona tanyo hanjeut teubit rumôh, padahal hana breuh lé.

"Because of the coronavirus, we are prohibited from leaving the house, although there is no more rice in the kitchen"

Analysis: The speech contained the presumption that it was forbidden to leave the house and that the rice had run out. it is interpreted that Because of the coronavirus we are not free to go out even though we are running out of rice. The use of the word padahal 'even though' indicates that the speaker is aware that the rice is running out, and the word even means something that is implied as a fact. This speech is included as factive presupposition and the presupposition of the speech can be interpreted based on its context, situation, and knowledge [2]. 


\section{Data (7)}

A: Sang watèe puasa hana jai lé ureng meukat, seubab kageubatasi aktivitas i luwa rumôh lé pemerintah.

"It seems that during the fasting period there are not many people paddling, because the government limits the activities".

Analysis: The speech has the presupposition that the fasting month is about to come, but outdoor activities have been limited. Also, the public is advised to stay away from the crowd. The utterances use the word sang 'seems' which can be understood only by the speaker's opinion but this assumption can be proven based on the facts. The fasting month is coming soon and the truth is that the activities are limited by the government. This statement is included in the type of factive presupposition [3].

\section{Existential Presupposition}

Data (8)

A: Nyambut damel bram wak? nanging empun ing libur sedaya 3 hari

'Are you still working, bro? But it's already 3 days off'

B: Bram taksih nyambut damel panjenengan. Dereng wong serat saking atasanipun

'Bram is still working. he has not received any letter from his boss yet'

C: Iyalah tiyang kantor dereng wong ingkang libur, dereng wong serat sakin sirah inggi pundi saged remen remen.

'of course, the office workers have not had any day off yet, there has been no letter from the boss yet, so they can't do as they please.

Analysis: This conversation has a presupposition that bram works in an office and has a supervisor who must be obeyed. there must be an official letter from the supervisor before taking the day off. Besides, this presupposition is also understood by speaker $\mathrm{C}$, which is shown in the utterance 'of course, the office workers have not had any day off yet, there has been no letter from the boss yet, so they can't do as they please.' This conversation is a type of Existential presupposition because it can be proved [2].

Data (9)

A: Na tunangan bak rumôh pPakak Sukur

'There's an engagement at Pak Sukur's house'

Analysis: The presuppositions appeared in the utterance $\mathrm{Na}$ tunangan bak rumôh Pak Sukur is that there is an event in Pak Sukur's house. Tunangan here is referred to an engagement event. This presumption can be recognized if there is an event, it can be proven by its existence. This speech is included in the Existential Presupposition type [2].

Data (10)

A: Baroe Linda bloe honda barô

'Yesterday, Linda bought a new motorcycle.'
Analysis: The presumption in this speech is that Linda has a new motorcycle. The utterances clearly indicate an existence, that is, presuppositions that are not only assumed to exist but also shows ownership; and it can be verified. The utterance that shows ownership is Baroe Linda bloe honda barô. And the existence of the motorbike assumed by the speaker can be verified [2].

Data (11)

A: Beuklam lôn jak u pasai, Kabéh seungue dum hana lé ureung meukat

'Yesterday, I went to the market. There are no more people selling

'Analysis: This speech has the presupposition that the market is closed, this speech is influenced by the context of the Covid19 outbreak, because the fear of being exposed to the virus, the market is getting quiet. The use of the word kabéh seungue can be interpreted as 'the market was busy'. This speech is included in an Existential presupposition which indicates the existence of a thing and can be verified $[5,6]$.

Data (12)

A: Lôn bunôe bengöh trôh haba, sidéh di Pidie jaya ka lockdown, hanjeut lé ureung mudik keudéh.

'I heard the news this morning; Pidie Jaya has been placed on lockdown, people could no longer go home.

Analysis: The speech has the presupposition that it is no longer allowed to go Pidie, the city has been locked down to protect themselves from the coronavirus outbreak, nobody from other areas are allowed to enter the area. The news was received by the speaker in the morning showed in the speech of Lôn bunôe bengöh trôh haba. This speech is included in an existential presupposition because it has facts that can be proven [6].

Data (13)

A: Na terimông dara barô bak rumôh wak nông aleuh uroe raya 'there is a wedding party at Wak Nong's house after Eid'

Analysis: The presupposition that arises in this conversation is that there is a wedding party, Eid Al-Fitr, and Wak Nong owns a house. This speech assumes that when the speech occurs it is not Eid Al-Fitr yet. This speech is an Existential Presupposition because it shows the reality and states an existence, that is, an event takes place at Wak Nong house after Eid Al-Fitr [2].

\section{Structural Presupposition}

\section{Data (14)}

A: Cék, peu asoe risol nyan?

'Cek, what's the filling of that risol?'

Analysis: The above speech shows the presupposition that the risol has the filling and there are various types of risol filling. In this speech, the speaker clarifies his/ her assumptions by ascertaining what the filling of the risol that he/ she sees. The speech indicates a structural presupposition because there is the use of the question word which indicates the presupposition of the speaker. This presumption is stated in the speech by questioning the interlocutor to prove the assumptions, and the 
answer is in the form of truth that can be accepted by the speaker $[5,6]$.

Data (15)

A: Wak, eneng iwak opo ae?

'What kind of fish do you have?'

Analysis: This speech has the presupposition that there are several types of fish, Person A asks to confirm what fish sold today by asking Wak, eneng iwak opo ae? The context of this speech is while fish buying. This speech indicates a structural presupposition because of the use of the question word in the speech and the answer is a truth that can be accepted by speakers $[5,6]$.

Data (16)

A: Bang,bakso eneng opo ora?

'Bang, is there meatballs?'

Analysis: The speech has the presupposition that there is a meatball seller, A asks Bang,bakso eneng opo ora? 'Bang, is there meatballs?' the speaker has an assumption that the meatballs have been sold out. The speech indicates that this is a structural presupposition because of the question mark from the speaker to prove his/ her assumption [2]

Data (17)

A: Kak, gulèe pu mantoeng neumé uroe nyôe ?

'kak, what are the vegetables today?'

Analysis: The speech has the presumption that there are several kinds of vegetables, then the speaker proves his/ her assumption with the question Kak, gulèe pu mantoeng neumé uroe nyôe ? the question was asked to justify the type of vegetable today. The speech indicates a structural presupposition with the use of the question word. These utterances can be analyzed with presuppositions and the speaker knows the validity of his/ her assumptions [2]

Data (18)

A: Wonten opo ing toples iku?

What's in the jar?

Analysis: The speech has the presupposition that there might be some food in the jar or it might be empty. Then the speaker proves by questioning what in the is. This speech is included in structural presupposition which states something as an object that is being discussed and understood by the speaker through the interrogative sentence structure validated by the question word $[5,6]$.

\section{E. Types of Non-factive Presuppositions}

Data (19)

A: Kupiké sit salah pemerintah keupue yak bi ureung cina ya kjak keunô ' oh tengôh lagènyôe keadaan.

'I think it is the government's fault, why would they allowed Chinese people to come here on this situation'

Analysis: The speech has the presumption that Chinese come to Indonesia and therefore, coronavirus spreads. This assumption is clearly understood by the speaker's utterance, but the truth of this assumption cannot be validated. The word kupiké, which means 'I think' has the meaning of the speaker's own opinion in which it cannot be proven. This speech is included in the type of non-factive presupposition $[5,6]$

Data (20)

A: Seandainya aku duwe pacar garang

'If only I have a handsome boyfriend'

Analysis: The speech has the presupposition that she does not have a handsome boyfriend and she wishes to have one. The speaker is still imagining what she is saying. It indicates that this presupposition is non-factive or unreal, this is evidenced by the word 'if' which is still imaginary and its existence cannot be proven $[5,6]$.

Data (21)

A: Menawi wawak gadhah pesawat piyambak

'If only Wawak had a private plane

'Analysis: This speech has the presupposition that wawak does not have an airplane. The use of the word Menawi as the presupposition and only wishful thinking 'if wawak has a private plane' indicates that this speech is included in the nonfactive presupposition type. it can be assumed through the utterance cannot be proven [2].

Data (22)

A: Adak meudéh lôn pih meutemé bantuan' I should have to get donation too'

Analysis: The speech has the presupposition that I do not get help, meaning that A does not get any donation, he/ she assumes or wants to get help like other people. The donation discussed here is the donation given because of the coronavirus pandemic. The speech is a type of non-factive presupposition in the form of an image of someone who cannot be validated the truth because the speaker uses the word harusnya meudéh 'should' [5,6].

\section{F. Lexical Presuppositions}

Data (23)

A: Pak Dina iki kita kudu melu latihan

'Sir, today we must attend the training'

B: Ya mula kita kudu siyap

'Yes, then we have to get ready'

Analysis: The speech has the presupposition that there is training today and they have not got ready yet, Person A tells B that today they have to follow the training. The interlocutor immediately understands the speaker's utterance and responds to the statement by telling them to get ready. This dialogue indicates a lexical presupposition, that is, the speaker gives a general statement without explaining, but the opponent understands it $[5,6]$.

Data (24)

A: Haikal mulai les bar intuk peringkat ke wolulas tko telong poluh siswa.

"Haikal started tutoring after ranked 18th out of 30 students." 
Analysis: The speech has the presupposition that Haikal was not tutoring and haikal was ranked 18th. Low rank requires Haikal to take a tutoring class. This speech includes lexical presupposition. This presupposition can be understood without being validated $[5,6]$

Data (25)

A: Aneuk lôn han lôn bi teubit lé uluwa

'I do not allow my son to go out anymore'

Analysis: This speech has the presupposition that his/ her child has not been outside, he/ she does not allow his/ her child to go out as usual because worrying about the condition of coronavirus. The use of the word han lôn bi teubit indicates that this is a lexical presupposition. Statements or utterances uttered by the speaker can be understood as their assumption $[5,6]$.

Data (26)A: Fira ka pijuet seulama jiolahraga

'Fira is getting slimmer after exercising'

Analysis: The speech contained the prejudice that Fira was fat and she didn't exercise before. The speakers say the word seulama which indicates that Fira was not exercising and was not thin before. this speech is a type of lexical presupposition, this presupposition is a presupposition obtained through speech which is interpreted with a general understanding $[5,6]$.

\section{Counterfactual Presupposition}

Data (27)

A: Seuandai jih peumerintah 'oh wate geutetapkan lockdown, geutanyôe geubi bantuan tiep- tiep rumôh.

'If only the government when they have decided to lockdown, they should give us a donation to each household.

Analysis: This speech has the presupposition that it is no longer allowed to do outdoor activities as usual, but no living allowance is given by the government. The use of the word seuandai jih 'if only' indicates that this is only the speaker's imagination. This speech is included in the counterfactual presupposition because the presupposition can be the opposite condition of the existing facts. in fact, there is a donation, it's just that not every house gets it [2]

Data (28)

A: Menawi ibu taksih gesang, mesthi liburan iki bakal seneng ning kampong.

"If the mother was still alive, we would have a very happy holiday in the village."

Analysis: This speech is in the context of a family left by their beloved mother, so they do not have a happy vacation. This statement shows that they assume that if their mother was still alive they will come home and have a happy vacation, but this assumption is in contrast with the fact. the holiday could also be unhappy even though the mother is still alive. This speech is included in the counter-factual presupposition [2].
Data (29)

A: Meunyôe hana virus Corona, warôengnyô pasti tetap ramé

"If there was no Coronavirus, this shop would still be crowded"

Analysis: This conversation has a presupposition that if there is no coronavirus the shop will be crowded. This assumption cannot be considered true because the shop could also be deserted for other reasons. The use of the word menyôe 'if' which could also be in contrast with the existing facts. This speech is included in the type of counter-factual presupposition or assumption with contrary facts [2].

\section{CONCLUSION}

The presuppositions in the speech of the Acehnese and Javanese ethnics in Geudubang Jawa village similar to presuppositions used by the general public, those are active, existential presuppositions, structural presuppositions, nonactive presuppositions, lexical presuppositions, and counterfactual presuppositions. The results show that every speech from the community has a presupposition that can be observed, all of the analyzed speeches are 29 speeches and the most widely used presupposition by the people of Geudubang Jawa village is the active presupposition. Based on the conclusions that have been described, the researcher proposes several suggestions, including (1) Research on presuppositions still needs to be continued so that each presupposition can be understood according to its context, (2) Research on presuppositions needs to be documented so that there is written material regarding the dominant presuppositions used of each region.

\section{REFERENCES}

[1] A Sutedi, Good Corporate Governance. Jakarta: Sinar Grafika, 2011.

[2] N.D. Astri, "Analisis Presuposisi pada Percakapan Mahasiswa FKIP UNPRI Tahun Ajaran 2019/2020," Bahasa Indonesia Prima, Vol.2, No $1,2020$.

[3] L.H. Hasan, Analisis Wacana Pargmatik. Bandung: Angkasa. Nadar, F X. 2009. Pragmatik dan Penelitian Pragmatik. Yogyakarta: Graha Ilmu, 2015. Purwo, Bambang Kaswanti. 1990. Pragmatik dan Pengajaran Bahasa. Yogyakarta: Kanisius.

[4] Sudaryanto, Metode dan Aneka Teknik Analisis Bahasa. Yogyakarta: Duta Wacana University, 2015.

[5] Yule, George, Pragmatik. Yogyakarta: Pustaka Pelajar. Yuliana, Nuryanti. 2011. "Analisis Pragmatik dalam Kartun Editorial" "Kabar Bang One" pada Program Berita Tv One". Jurnal Linguistika. Surakarta University, 2016.

[6] A. Wijayanti, "Presuposisi dan Implikatur pada Stand up Comedy Indonesia," Transformatika, Vol. 12, No. 2, 2016. 